\title{
INVESTIGATION OF CURRENT DENSITY, MAGNETIC FLUX DENSITY, AND OHMIC LOSSES FOR SINGLE-VEINED, LITZ AND FOIL STRUCTURED CONDUCTORS AT DIFFERENT FREQUENCIES FARKLI FREKANSLARDAKİ TEK-DAMARLI, LİTZ VE FOLYO YAPILI İLETKENLERİN AKIM YOĞUNLUĞU, MANYETİK AKI YOĞUNLUĞU VE OMİK KAYIPLARININ ARAŞTIRILMASI
}

\author{
Serdal ARSLAN ${ }^{1}$, Illhan TARIMER ${ }^{2}$, M. Emin GÜVEN ${ }^{3}$ \\ 1Birecik Meslek Yüksekokulu, Harran Üniversitesi, 63400, Birecik, Şanlıurfa. \\ elkserdal@gmail.com \\ 2Teknoloji Fakültesi, Muğla Sıtkı Koçman Üniversitesi, 48170, Muğla. \\ itarimer@mu.edu.tr \\ ${ }^{3}$ Teknoloji Fakültesi, Gazi Üniversitesi, Teknikokullar, 06500, Ankara. \\ mguven@gazi.edu.tr
}

\section{Abstract}

Today, although medium and high frequencies have been provided a significant reduction in the size of machine, it is known that as the more frequency increases, the higher losses at conductors. In this study, wire losses of the same cross section but different structures are examined by finite elements method. Also, depending on the exchange rate in wires at conductors, changes of current density, magnetic flux density and ohmic losses were investigated. The use of different structured wires of conductors at different frequencies has been compared in terms of their losses, and given the graphics regarding to the design by special design software.

Keywords: Conductor, Wire, Skin effect, Litz and foil conductor, Conductor losses.

\section{Introduction}

At present, single veined conductors are commonly being used within $50 \mathrm{~Hz}$ operating Electrical machine windings like transformer, induction coil. Since that ferrite alloyed core material with amorphous and nanocrystalline have frequently produced, design and use of high power but small sized electrical machines have been begun to appear frequently [1].

The magnetic field created by the current flowing through the conductor is static due to no eddy currents occur in the DC. The oscillating magnetic field (in the $\mathrm{AC}$ ) induces currents in conductors. These induced currents affect the computation of inductance for the impedance matrix, causing it to be different from the equivalent DC computation of inductance [2]. At high frequencies, Eddy losses are being shown, and frequency increases, Eddy losses increase as well. This is why because skin and proximity effect force Eddy losses to increase. Ferreira [3] has examined losses of single veined conductors at high frequencies.

Nowadays, various conductors in order to reduce loss of copper are being used, and Litz conductor is one of them. Litz conductors are formed as that more than one wire which isolated from each is clustered. Isolating material minimizes heat to be happened at conductor; material of conductor is made from high resistant copper alloy. More frequency
Özet

Günümüzde, orta ve yüksek frekanslar, makine boyutunda önemli derecede küçülme sağlamasına rağmen bu frekanslardan kaynaklanan kayıpları da beraberinde getirmektedir. Elektrik makinalarında meydana gelen kayıplar özel sargı tasarımları ile azaltılabilmektedir Bu calısmada aynı kesitteki tek damarlı iletken, litz iletken ve bakır folyo iletken kayıpları sonlu elemanlar yöntemi ile incelenmiștir. Ayrıca frekansın değișimine bağlı olarak iletkenlerdeki akım yoğunluğu, manyetik akı yoğunluğu ve omik kayıplar bir tasarım programı yardımıyla incelenmiş ve elde edilen grafikler verilmiştir.

Anahtar kelimeler: İletken, Tel, Deri etkisi, Litz ve folyo iletkeni, İletken kayıpları.

increases more reactance increase. As result of this, effective resistance of winding changes and so, difference between reactance and effective resistance rises up. Change of frequency effects structure of Litz winding [4]. Sullivan has worked to reduce losses at Litz conductors by his study [5].

It is now possible that electrical machines' windings can be wound with foil conductors nowadays. Dispersion of current density at foil balances asymmetries at windings, reduces axial forces and makes heat dispersion as homogeneous [6]. Foil windings are used extensively for high DC current applications since they have small DC resistances [7]. Dowell [8] has calculated resistance coefficient of foil conductors' losses at high frequency. Odendaal and et. al. [9] have made analytical solutions for determining Eddy currents at foil windings.

Podoltsev and et.all developed a numerical model for calculation of eddy-current losses in a multiturn winding of a high-frequency transformer [16]. Bartoli and et.all. studied the parasitic effects in stranded, twisted, and Litz wire windings operating at high frequencies [17]. Tourkhani and Viarouge presented an accurate analytical model of losses in round Litz wire windings [18]. Ferreira introduced the analysis, and a method to analyse stranded or litz wire conductors in multilayer windings [19]. Ferrieux and et all. presented current density distribution and losses in a large air-gap transformer composed of two E cores and two windings using 
homogenization and 3-D FEM [20]. Sheng and et all. reported a planar litz structure in their paper, aiming to reduce the highfrequency losses in planar windings to demonstrate the benefits of a unique conductor design [21]. In another work, it has been studied solving processes aiming to magneto static, electro static eddy current, and thermal analysis by finite elements method [22]. Driesen and et all considered the thermal field and thermal models of a transformer having 50 secondary foils [23].

In this study, losses of different structured but same cross sectioned conductors like single veined, Litz and copper foil conductor have been analyzed with finite elements method (by Ansoft Maxwell 2D program). The current densities and ohmic losses of these conductors have been investigated for different frequencies.

\section{Loss Calculations in Wire Conductors via Finite Elements Methods}

Solid conductors are sometimes called massive conductors or thick conductors, where current density is distributed nonuniformly over their cross section due to skin effect. Their physical phenomenon is very difficult to study using the traditional analytical approach. One of the main causes is the eddy-current effect in the solid conductors [10]. Skin effect of a conductor at high frequency is determined as given in Equation 1.

$$
\delta=\sqrt{\frac{\rho}{\pi \mu_{0} \mu_{r} f}}
$$

where: $\delta$ - thickness of skin occurred in a conductor, $\rho$ conductivity as $\Omega \mathrm{mm}^{2} / \mathrm{m}, \mu_{0}$ - magnetic permittivity of space, $\mu_{r}$ - relative permittivity, $f$ - frequency.

The eddy current field Ansoft's simulator allows us to simulate the effects of time-varying currents in conductor structures. A two-dimensional (2D) FEM is used to compute the magnetic fields which lie in $x-y$ plane of the model. The magnetic vector potential $(A)$ and the electric field $(E)$ are represented by only a component which lies in $z$ direction of the model. $\phi$ is a constant for each cross section of a conductor. The field problem is often simplified by assuming that $J=\left[0 ; 0 ; J_{z}\right]$. The solver calculates the eddy currents by solving for $A$ and $\phi$ in the field equation (Eq. 2):

$$
\nabla \times \frac{1}{\mu}(\nabla \times A)=(\sigma+j \omega \epsilon)(-j \omega A-\nabla \emptyset)
$$

where: $\phi$ - the electric scalar potential, $\mu$ - the absolute magnetic permeability, $\omega-$ the angular frequency at which all quantities are oscillating, $\sigma$ - the conductivity, and $\varepsilon$ - the absolute permittivity.

Loss calculation from conduction component of the current density $\left(J_{c}\right)$ is given as in Equation 3.

$$
l_{c}=\sigma E
$$

By Joule's law, the time-averaged power density is written as given in Equation 4:

$$
P_{d}=\frac{1}{2} R_{d}\left(E_{x} j_{c}^{2}\right)
$$

In order to solve resistance of the current loop $(R), J_{c}$ will be computed for each conductor (Equation 5).

$$
R=\frac{1}{2 \sigma I^{2}} \int J_{c} J_{c}^{*} d \Omega
$$

where: $\sigma$ - conductivity, $J_{c}$ - current density.

Each sub solution represents the contribution of a current loop toward the matrix. After solving it for J at all conductors;

the system will compute the resistance matrix. The selfimpedance of one loop is given as in Equation 6.

$$
z_{11}=R_{1}+j \omega L_{11}
$$

where: $R_{1}$ - internal resistance of the current loop, $L_{11}$ - selfinductance of the loop, and $j \omega L_{11}$ - inductive reactance of the loop.

\section{Modelling and Analysis of Wire Conductors}

In this study, it has been considered that single veined, copper foil and Litz conductor are modelled and analyzed. In case of total surface current is specified, the current density is assumed to be uniform. In order to equalize cross sectional area of conductor, diameter of a single veined conductor was taken as $d=5.819871133 \mathrm{~mm}$, width of a foil conductor was taken as $w=0.5 \mathrm{~mm}$ and height of a foil conductor was taken as $h=53.177313 \mathrm{~mm}$. The finite element model of the stranded conductor in a multi-conductor system is not valid for skin and proximity effects [11]. So the Litz conductor are being formed from 525 separate solid wires which each of them was isolated and their diameters are $0.254 \mathrm{~mm}$. Current densities, magnetic field densities, and ohmic losses for these conductor types have been examined at several frequencies. Furthermore, scale values of figure and graphics have been kept as constant in terms of obtaining advantageous and disadvantageous between these conductors.

In the analysis done, 53550 meshes for single veined conductor, 347714 meshes for Litz conductor, and 27490 meshes for foil conductor have been happened. Since Litz conductor has got a complex structure, however there seem some difficulties in modeling Eddy currents, they need more extensive meshes for modeling [12].

The 2D Eddy current analysis of the single veined conductor for $0.001 \mathrm{~Hz}, 50 \mathrm{~Hz}, 1 \mathrm{kHz}, 10 \mathrm{kHz}, 50 \mathrm{kHz}$ frequencies have been done and dispersions of current densities have shown as in Figure 1.

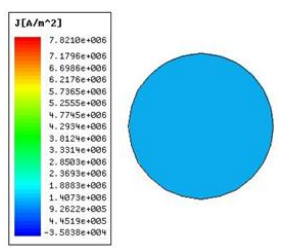

a) $0.001 \mathrm{~Hz}$

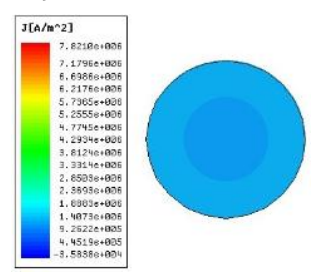

c) $1 \mathrm{kHz}$

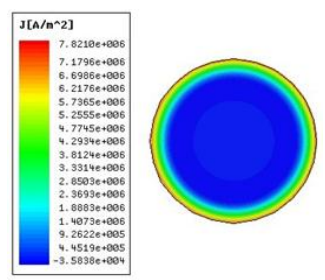

e) $50 \mathrm{kHz}$

Figure 1: Dispersion of current densities at single veined d) $10 \mathrm{kHz}$
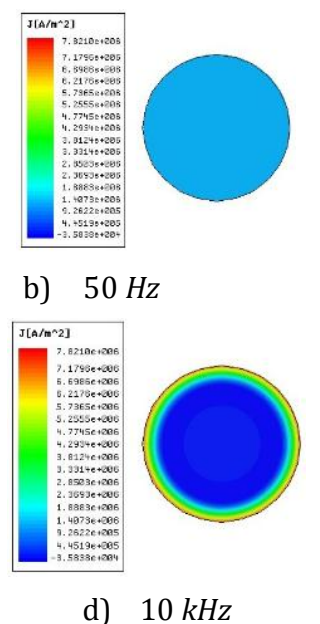

\footnotetext{
conductor for several frequencies.
} 
As seen from Figure 1, it is clearly seen that skin effect at $1 \mathrm{kHz}$ and upper frequencies are dispersed. It is understood that current density increases, when it goes to surface of conductor. Since that the wire is divided into many concentric cylinders of equal cross section area, the internal inductance $\left(L_{i}\right)$ accounts for the magnetic energy distributed through the cylindrical sections. The $L_{i}$ blocks the current from the wire interior, and forces it to be able to flow over the surface. The negative change of imaginary component of the current density arises from substitution current at $10 \mathrm{kHz}$ and $50 \mathrm{kHz}$ frequencies. More frequency increase, higher substitution current arises to coastal points of the conductor; at the same time, current density decreases to center of the conductor. So the current tails off exponentially within the conductor (Figure 2), [13].

The 2D Eddy current analysis of Litz conductor for $0.001 \mathrm{~Hz}$, $50 \mathrm{~Hz}, 1 \mathrm{kHz}, 10 \mathrm{kHz}, 50 \mathrm{kHz}$ frequencies have been done and dispersions of current densities have given as shown in Figure 3.

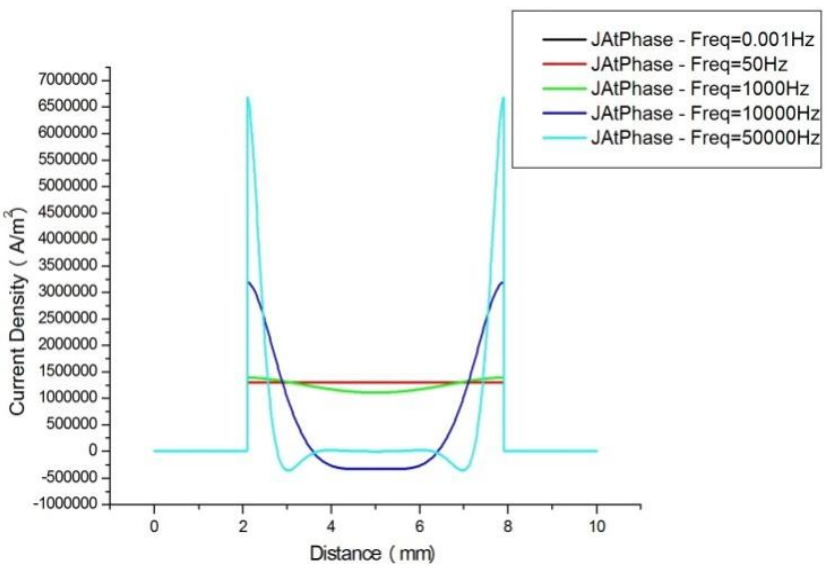

Figure 2: Change of current density at the single veined conductor along line.
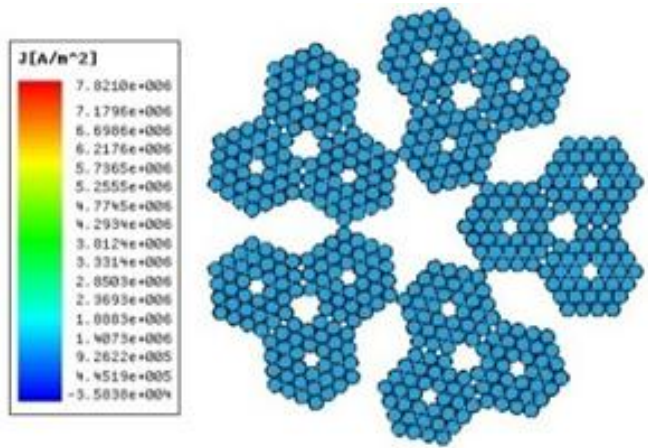

(a) $0.001 \mathrm{~Hz}$
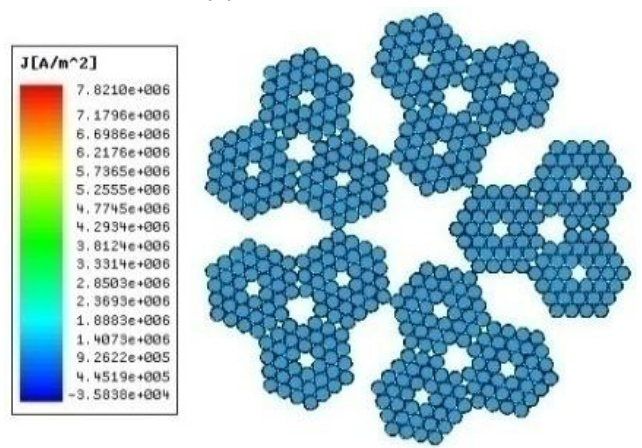

(b) $50 \mathrm{~Hz}$

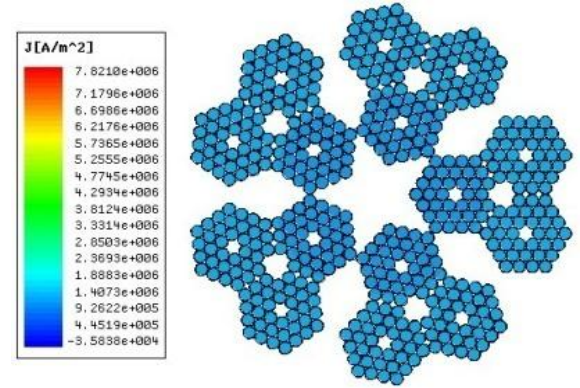

(c) $1 \mathrm{kHz}$

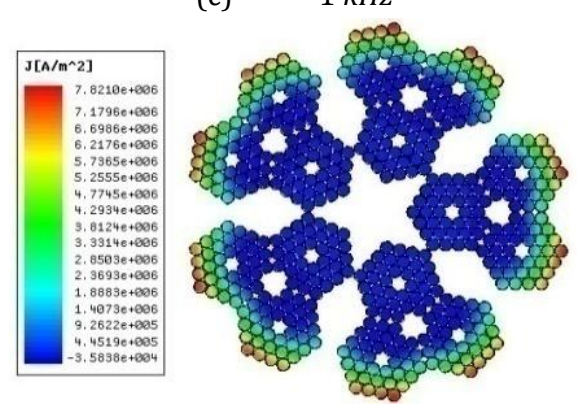

(d) $50 \mathrm{kHz}$

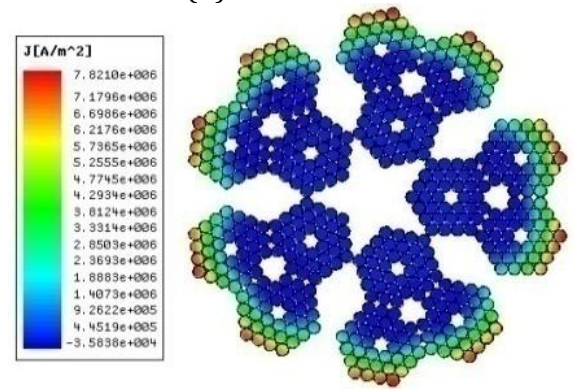

(e) $10 \mathrm{kHz}$

Figure 3: Dispersion of current densities at litz conductor.

It is clearly seen that dispersion of current density is occurred at each individual wire of Litz conductor in Figure 4. From Figure 4, current density related with frequency is being decreased as exponentially through conductor center. When the frequency is $10 \mathrm{kHz}$ the substitution current goes through to the conductor's center as it is as in single veined conductor. It spreads to the coast of the conductor as parallel to the frequency increases. At $50 \mathrm{kHz}$, the current density at Litz conductor have been dropped to approx. $5.5 \mathrm{~A} / \mathrm{mm} 2$ while the single veined conductor's current density was about 6.5 $\mathrm{A} / \mathrm{mm} 2$. The change of current density has increased the current carrying capacity which goes through to the center of the conductor (Figure 5).

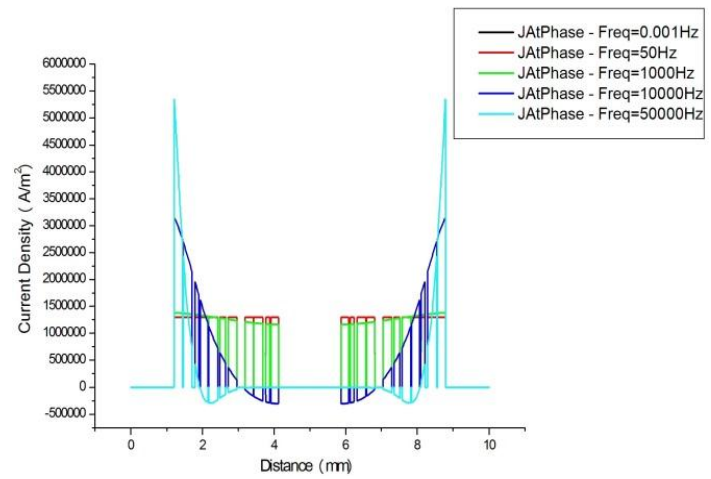

Figure 4: Change of current density at litz conductor along line. 
The dispersion of current density at the foil conductor is seen in Figure 5. From Figure 5, it has been seen that current density through center of conductor is not being decreased in a large amount comparing to the single veined and Litz conductors'. However it is seen that the current density is rather big towards to the foil conductors' corner points. Since the current density at foil conductor spreads as homogenous, it can be said that the forces to be happened at foil windings would be scattered as well.
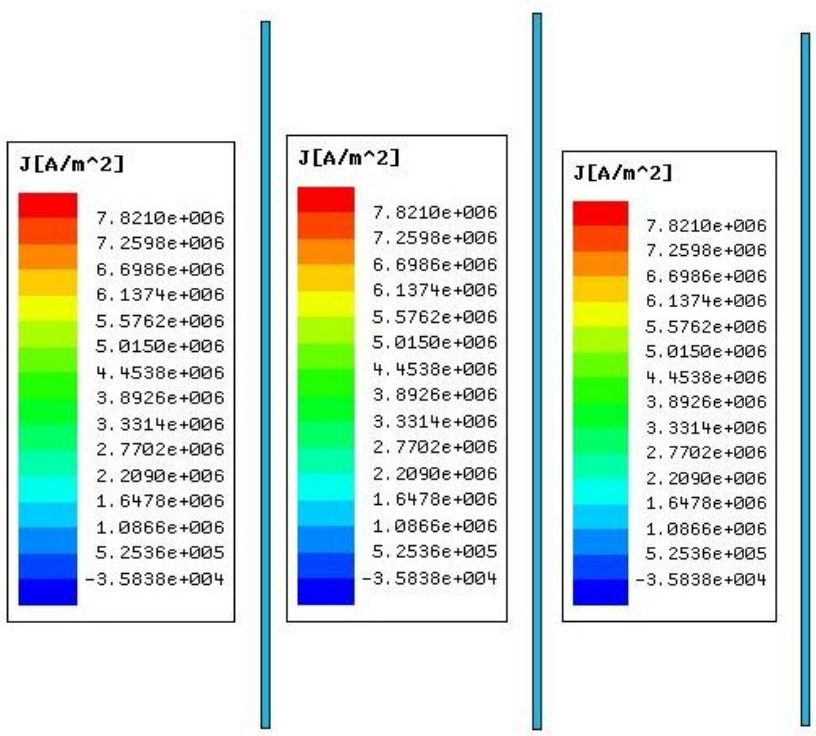
(a) $0.001 \mathrm{~Hz}$
(b) $50 \mathrm{~Hz}$
(c) $1 \mathrm{kHz}$

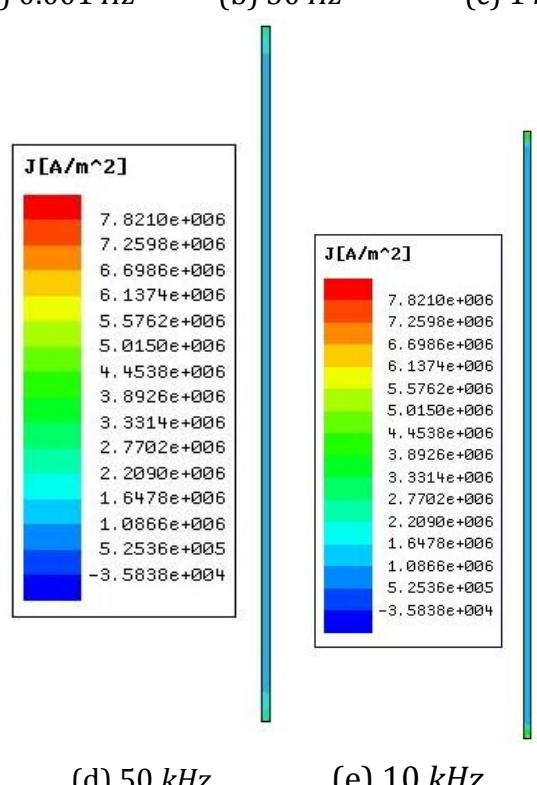

Figure 5: Dispersion of current densities at copper foil conductor.

More frequency changes lower current density towards conductor centre, since skin effect. It has been seen that the substitution current wouldn't be obtained at frequency interval of $10 \mathrm{kHz}-50 \mathrm{kHz}$ rather than single veined and Litz conductors. The change of current densities for several frequencies at foil conductor is given in Figure 6.

The changing of magnetic field densities along line according to logarithmic change of frequencies for three types of conductors have been obtained and shown in Figure 7.

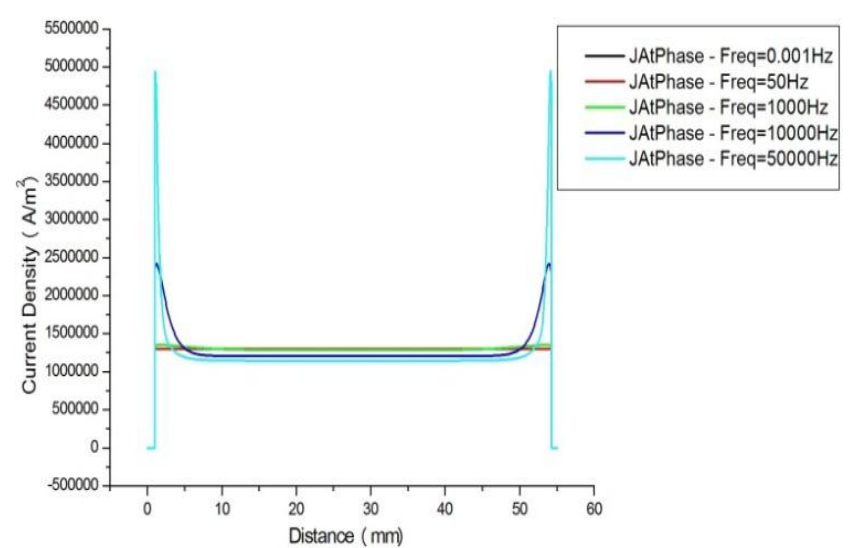

Figure 6: Change of current density at foil conductor along line.

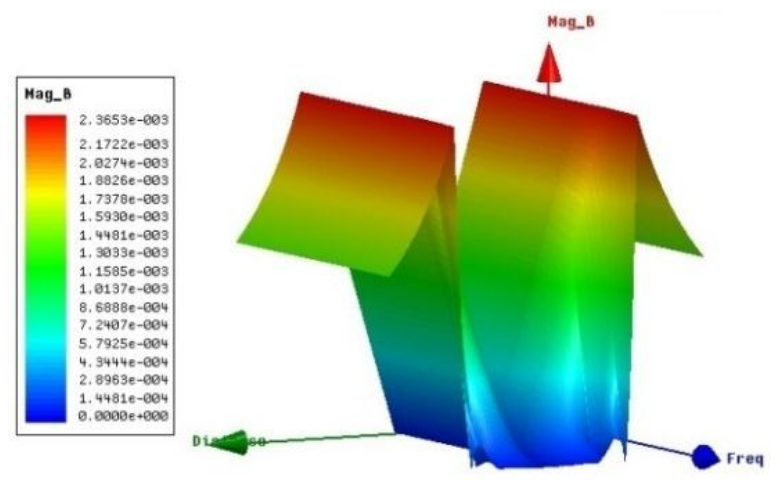

a)

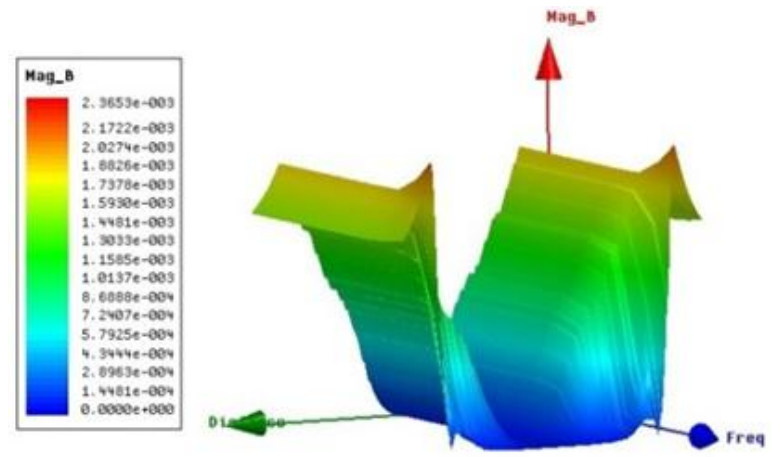

b)

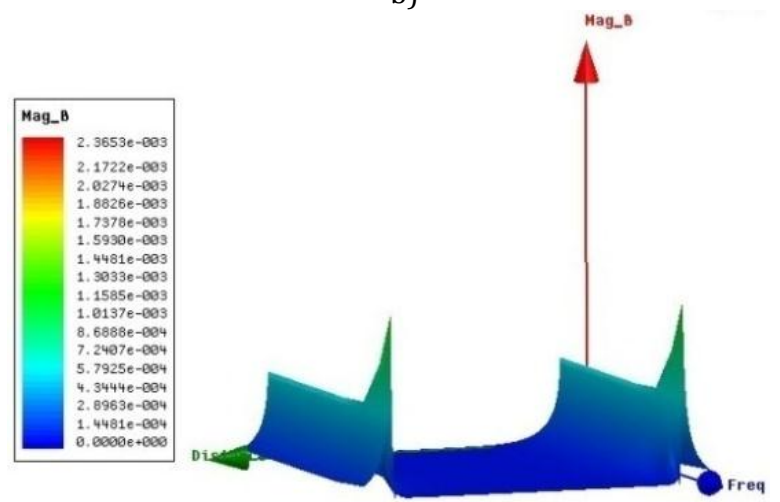

c)

Figure 7: Change of magnetic field densities along line according to logarithmic change of frequency, respectively: a) Single veined conductor, b) Litz conductor, c) Copper foil conductor. 
The magnetic fields occur since the currents flow inside and outside the conductors. The intensity of magnetic field which seemed around inner and outer surfaces of the certain conductors does not change until the frequency ascends to $10 \mathrm{kHz}$ and $50 \mathrm{kHz}$. The eddy currents are limited by their self-magnetic fields at high frequencies and so, they are said to be as inductance-limited [14-15]. The ohmic losses density is shown in Figure 8 as labeled as $P_{d}$.

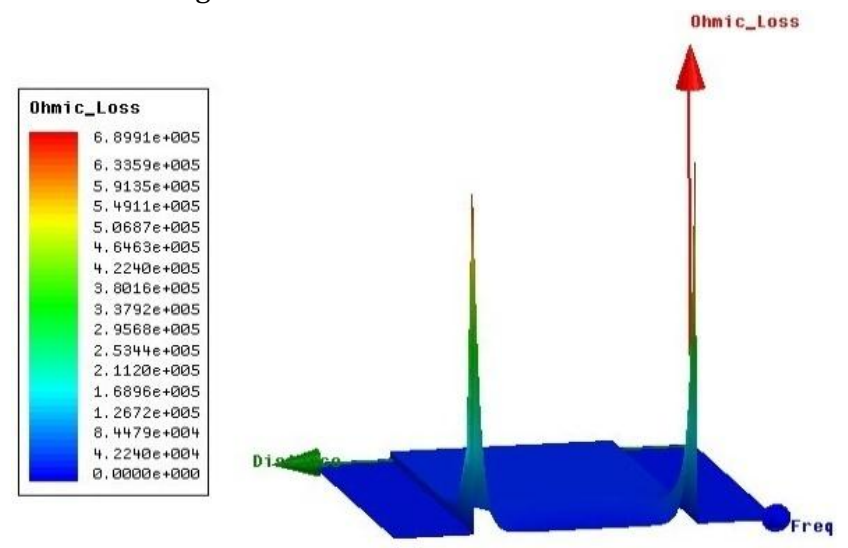

a)

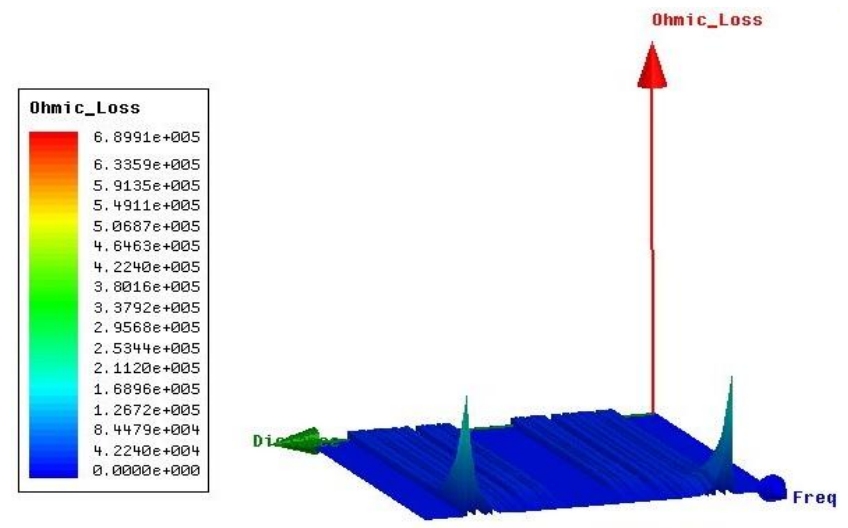

b)

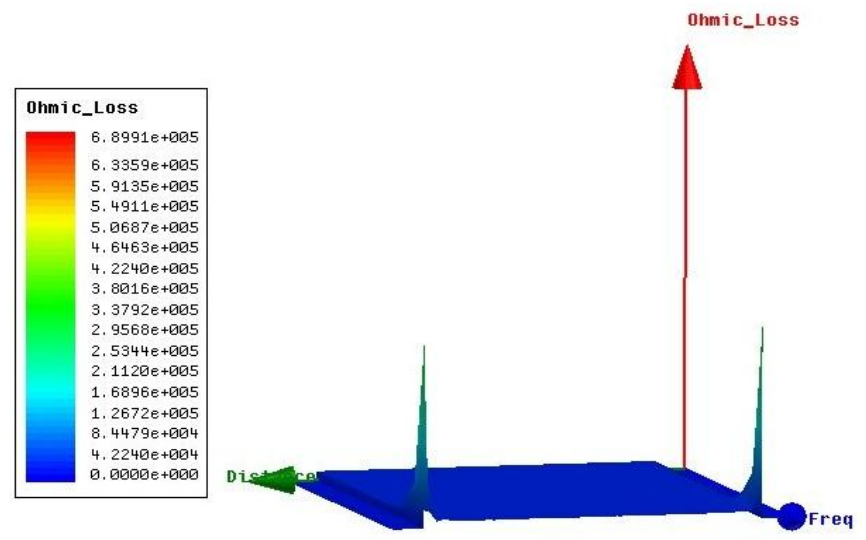

c)

Figure 8: Change of Ohmic losses along line according to logarithmic change of frequency: a) Single veined conductor, b) Litz conductor, c) Copper foil conductor.

The alternating current resistances of single veined, Litz and foil conductors are given in Figure 9. The calculated Ohmic losses of these conductors are given in Table 1:
Table 1: Ohmic losses.

\begin{tabular}{cccc}
\hline $\begin{array}{c}\text { Frequency } \\
(\mathrm{Hz})\end{array}$ & $\begin{array}{c}\text { Single veined } \\
\left(\mathrm{W} / \mathrm{mm}^{2}\right)\end{array}$ & $\begin{array}{c}\text { Litz } \\
\left(\mathrm{W} / \mathrm{mm}^{2}\right)\end{array}$ & $\begin{array}{c}\text { Foil } \\
\left(\mathrm{W} / \mathrm{mm}^{2}\right)\end{array}$ \\
\hline 0.001 & 0.0145126091 & 0.0145124793 & 0.0145140364 \\
50 & 0.0145263874 & 0.0145223329 & 0.0145190276 \\
1000 & 0.0197563347 & 0.0182430034 & 0.0163765785 \\
10000 & 0.1520310806 & 0.1061876214 & 0.0712204950 \\
50000 & 0.6893835497 & 0.2462560859 & 0.2905872400 \\
\hline
\end{tabular}
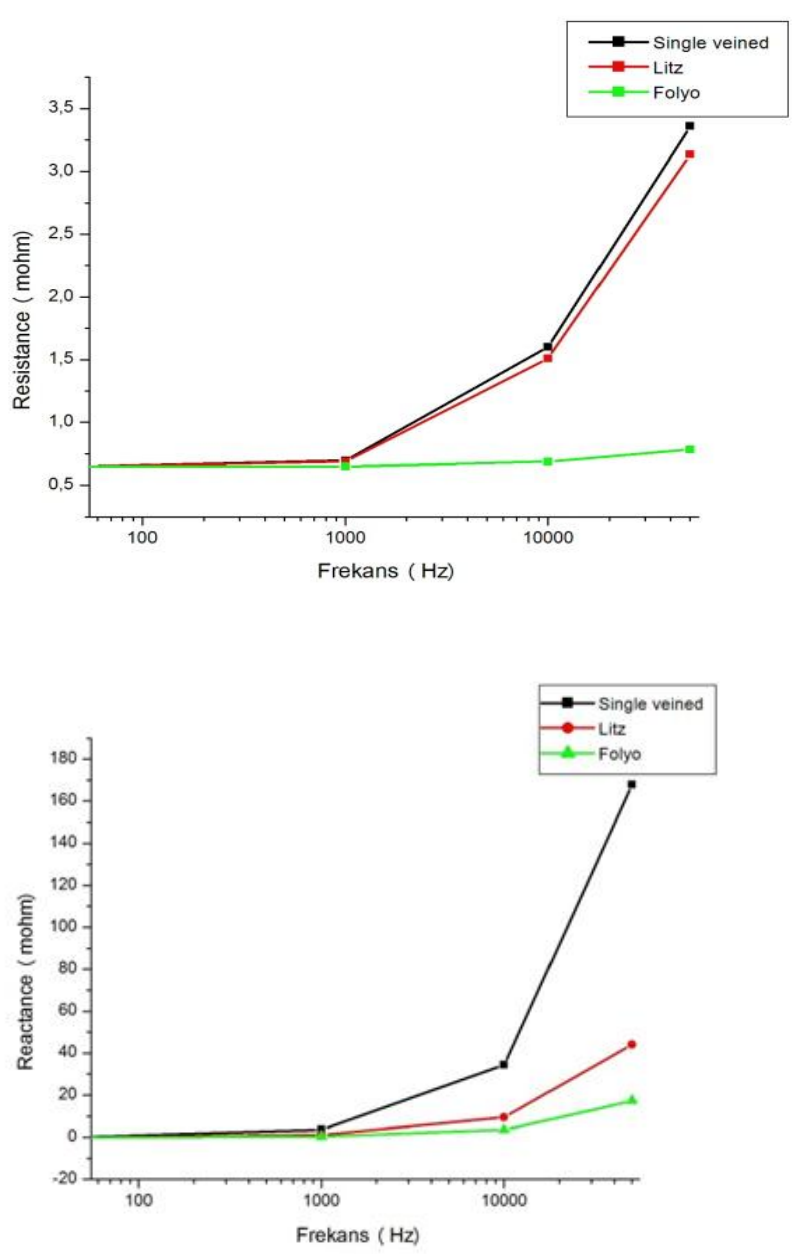

a)

Figure 9: Change of impedance: a) Resistance, b) Inductive Reactance.

Table 1 gives the loss density for three conductor structures regarding to the change of frequency. As known, there seems a proximity effect within the sheaves which carry current at same direction. From the Table 1, in spite of proximity effect, it is inferred that the loss occurred in Litz conductor at high frequencies $(50 \mathrm{kHz})$ would be obtained lower rather than the loss occurred at folio conductor.

When a conductor is used at Direct Current, the ohmic losses within whole cross sectional area of conductor are equally dispersed. However the frequency changes, the losses at centre of the conductor decreases gradually. This reduction eventuates from reactance effect at middle of the conductor is decreased. 


\section{Results}

In this study, several types of copper conductors' wires which have same cross sectional area; different geometrics have been investigated according to working at different frequencies. When structure of conductor is changed, their losses are being decreased at higher frequencies. Furthermore the resistance ratio $\left(R_{a c} / R_{d c}\right)$ changes substantially depending upon change of frequency. The geometrical change at conductor's structure effects current density based upon frequency change. In spite of the current density rises up at corner points of the conductor for high frequency runs, the function of change of current density at inner areas of conductor changes as well. Since this change, geometrics of the conductor to be used within windings of such electrical machines to be designed and produced for high frequency runs quite hold an important place in.

\section{References}

[1] Moses, J., " Iron-based Amorphous ribbon- challenges and opportunity for power applications", Journal of Optoelectronics and Advanced Materials, Vol. 4, nr 2, 231-236, 2002.

[2] Ansoft v14, Eddy current solution help file, http://softwaretopic.informer.com/ansoft-maxwelltutorial-free/ October 2012.

[3] Ferreira, J. A., "Improved analytical modeling of conductive losses in magnetic components", IEEE Transactions Power Electronics, nr 1, 127-131, 1994.

[4] http://www.newenglandwire.com/litz.asp, 31.08.2012.

[5] Sullivan, C. R., McCurdy, J. D., and Jensen, R. A., "Analysis of minimum cost in shape-optimized litz-wire inductor windings", IEEE Power Electronics Specialists Conference, Vol. 3, 1473-1478, 2001.

[6] Gersem, H. D., Hameyer, K., "A Finite element model for folio winding simulation", IEEE Transactions on Magnetics, Vol. 37-5, 3427-3432, 2001,

[7] Pollock, J. D., Sullivan, C.R., "Loss models for shaped folio windings on low-permeability cores", IEEE Power Electronics Specialists Conference, 3122-3128, 2008.

[8] Dowell, P. L., "Effects of eddy currents in transformer windings", Proceedings of the IEE, $\mathrm{nr}$ 8, 1387-1394, 1996.

[9] Odendaal, W.G., Ferreira, J. A., Cronje, W.A., "Combined numeric and analytic methods for folio winding design", Power Electronics Specialists Conference, PESC '94, 25th Annual IEEE June 1994, 843-849, 1994.

[10] Fu, W.N., Zhou, P., Lin, D., Stanton, S., Cendes, Z.J., "Modeling of solid conductors in two-dimensional transient finite-element analysis and its application to electric machines", IEEE Transactions on Magnetics, Vol. 40, $\mathrm{nr}$ 2, 426-434, 2004.

[11] De Gersem, H., Hameyer, K., "A Multi-conductor model for finite element Eddy current simulation", http://www.esat.kuleuven.be/electa/publications/fullte xts/pub 727.pdf 05.09.2012.

[12] Driesen, J., Deliége, G., Belmans, R., and Hameyer, K., "Coupled thermo-magnetic simulation of a folio-winding transformer connected to a non-linear load", IEEE Transactions on Magnetics, Vol. 36, nr 4, 1381-1385, 2000.

[13] Lloyd, H.D, "Eddy current losses in transformer windings and circuit wiring", Unitrode/TI Magnetics Design Handbook, Slup 197.

[14] Abdelbagi, A. H., "Skin and proximity effects in two parallel plates", MSc. Thesis, Wright State University, 88 p. 2007.

[15] Whitman, D., "Electromagnetic fields, power losses, and resistance of high-frequency magnetic devices", MSc. Thesis, Wright State University, 113 p, 2010.

[16] Podoltsev, A.D., Kucheryavaya, I.N., and Lebedev, B.B., "Analysis of effective resistance and eddy-current losses in multiturn winding of high-frequency magnetic components", IEEE Transactions On Magnetics, Vol. 39, No. 1, pp. 539 - 548, January 2003.

[17] Bartoli, M., Noferi, N., Reatti, A., Marta, S.V., Kazimierczuk, M.K., "Modeling Litz-wire winding losses in highfrequency power inductors", Power Electronics Specialists Conference, PESC '96, 27th Annual IEEE, ISBN: 0-7803-3500-7, Vol. 2, pp. 1690-1696. 1996.

[18] Tourkhani F., and Viaroug, P., "Accurate Analytical Model of Winding Losses in Round Litz Wire Windings" IEEE Transactions On Magnetics, Vol. 37, No. 1, pp. 538 - 543, January 2001.

[19] Ferreira, J.A., "Analytical computation of AC resistance of round and rectangular litz wire windings", IEE Proceedings-B, Vol. 139, No. 1, pp. 21-25, 1992.

[20] Ferrieux, J., Meunier, G., Periot, R., "Modeling of losses and current density distribution in conductors of a large air-gap transformer using homogenization and 3-D FEM", Magnetics, IEEE Transactions on, ISSN : 0018-9464, pp. 763-766, Feb. 2012.

[21] Wang, S., Rooij, M.A., Odendaal, W.G., Daniel van Wyk, Fellow, J., and Boroyevich, D., "Reduction of highfrequency conduction losses using a planar litz structure", Power Electronics, IEEE Transactions on, Vol. 20 , Issue 2, pp. 261-267, 2005.

[22] Fenercioğlu, A., Tarımer, İ., "Solution processes of a magnetic system's magneto static analysis with Maxwell 3D field simulator", Selçuk University Journal of Technical-Online, ISSN 1302/6178, Vol. 6, No. 3, pp. 221-240, 2007.

[23] Driesen, J., Deliege, G., Belmans, R., "Hameyer, K. "Coupled thermo-magnetic simulation of a foil-winding transformer connected to a nonlinear load", Magnetics, IEEE Transactions on, Vol. 36, Issue 4, pp. 1381-1385, 2000. 